\title{
ANALISIS KEYAKINAN DIRI (SELF EFFICACY) SISWA SMA DALAM MEMECAHKAN MASALAH MATEMATIKA DITINJAU DARI PERBEDAAN GENDER
}

\author{
Candy Alfa Agustina ${ }^{1}$, Suesthi Rahayuningsih ${ }^{2}$, Ngatiman ${ }^{3}$ \\ Universitas Islam Majapahit, Jalan Raya Jabon KM 0,7 Mojokerto \\ candy.alfa33@gmail.com
}

\begin{abstract}
Abstrak
Keyakinan diri (self efficacy) siswa dalam memecahkan masalah matematika dapat dipengaruhi oleh perbedaan gender, sehingga dengan gender yang berbeda keyakinan diri (self efficacy) siswa dalam memecahkan masalah matematika juga berbeda. Penelitian ini bertujuan untuk mendeskripsikan keyakinan diri (self efficacy) siswa SMA dalam memecahkan masalah matematika ditinjau dari perbedaan gender. Penelitian ini merupakan penelitian deskriptif dengan pendekatan kualitatif yang dilaksanakan di kelas X MIPA 2 SMA Negeri 1 Kutorejo. Subjek penelitian terdiri dari satu siswa laki-laki dan satu siswa perempuan. Instrumen penelitian terdiri dari Tes Keyakinan Diri (TKD) dan pedoman wawancara. Berdasarkan hasil analisis data diperoleh hasil sebagai berikut: subjek laki-laki memiliki pandangan yang optimis dalam memecahkan masalah matematika dengan berpikir optimis, menyebutkan beberapa informasi penting, menyatakan tujuan, dapat memahami permasalahan, yakin dengan yang dipahami dan penyelesaiannya, menyatakan strateginya dan yakin dengan strategi yang dilakukan. Subjek gigih dalam memecahkan masalah matematika dengan tidak merasa kesulitan dan tidak merasa putus asa menyelesaikan permasalahan. Subjek yakin akan kemampuan diri yang dimiliki dalam memecahkan masalah matematika dengan menjelaskan dan yakin dengan cara yang digunakan. Subjek menyikapi situasi dan kondisi yang beragam dengan cara yang baik dan positif dalam memecahkan masalah matematika dengan berusaha, merasa tidak memiliki kekurangan, dan tidak merasa stres dalam menyelesaikan permasalahan. Sedangkan subjek perempuan memiliki pandangan yang optimis dalam memecahkan masalah matematika dengan berpikir optimis, menyebutkan beberapa informasi, menyatakan, dapat memahami, yakin dengan yang dipahami dan penyelesaiannya, menyatakan strateginya dan yakin dengan strategi yang dilakukan. Subjek gigih dalam memecahkan masalah matematika dengan sedikit merasa kesulitan dan tidak merasa putus asa. Subjek yakin akan kemampuan diri yang dimiliki dalam memecahkan masalah matematika dengan menjelaskan dan yakin dengan cara yang digunakan. Subjek menyikapi situasi dan kondisi yang beragam dengan cara yang baik dan positif dalam memecahkan masalah matematika dengan merasa kebingungan, kurang faham terhadap masalah, dan sedikit terburu-buru dalam menyelesaikan permasalahan.
\end{abstract}

Kata Kunci: Keyakinan Diri, Matematika, Perbedaan Gender

\begin{abstract}
Students 'self-efficacy in solving mathematical problems can be influenced by gender differences, so that with gender different students' self-efficacy in solving mathematical problems are also different. This study aims to describe the self-efficacy of high school students in solving mathematical problems in terms of gender differences. This research
\end{abstract}


is a descriptive study with a qualitative approach carried out in class X MIPA 2 SMA Negeri 1 Kutorejo. The research subjects consisted of one male student and one female student. The research instrument consisted of a Self Efficacy Test (TKD) and interview guidelines. Based on the results of data analysis obtained the following results: male subjects have an optimistic view in solving mathematical problems by thinking optimistically, mentioning some important information, stating goals, being able to understand the problem, confident of what is understood and the solution, stating the strategy and confident with the strategy which is conducted. Subjects are persistent in solving mathematical problems by not feeling difficult and not feeling desperate to solve problems. Subjects are convinced of their own abilities in solving mathematical problems by explaining and confident in the method used. Subjects respond to diverse situations and conditions in a good and positive way in solving mathematical problems by trying, feeling they have no shortcomings, and not feeling stressed in solving problems. While the female subject has an optimistic view in solving mathematical problems by thinking optimistically, mentioning some information, stating, being able to understand, being sure of what is understood and solving it, stating its strategy and being sure of the strategy. Subjects are persistent in solving mathematical problems with little difficulty and not feeling hopeless. Subjects are convinced of their own abilities in solving mathematical problems by explaining and confident in the method used. Subjects respond to diverse situations and conditions in a good and positive way in solving mathematical problems by feeling confused, lacking in understanding of problems, and a little rushed to solve problems.

Keywords: Self Confidence, Mathematics, Gender Differences

\section{Pendahuluan}

Pendidikan matematika mempunyai peran yang sangat penting karena matematika merupakan ilmu dasar yang digunakan secara luas dalam berbagai bidang kehidupan. Menurut Chambers (dalam Novferma, 2016: 77) matematika merupakan suatu ilmu mengenai pola-pola abstrak yang memiliki karakteristik sebagai alat untuk memecahkan masalah, sebagai pondasi kajian ilmiah dan teknologi, serta dapat memberikan cara-cara untuk memodelkan situasi dalam kehidupan nyata. Subarinah (2013: 524) menyatakan bahwa pemecahan masalah merupakan salah satu komponen dalam tujuan pembelajaran matematika yang tertuang dalam standar nasional pendidikan di Indonesia. Oleh karena itu, dalam pembelajaran matematika pemecahan masalah memiliki peranan yang sangat penting.

Pemecahan masalah merupakan suatu kondisi berupa masalah yang metode pemecahannya tidak diketahui sebelumnya (Hidayati, 2015: 26). Pemecahan masalah bertujuan untuk menemukan solusi, dimana siswa harus memperdayakan dan mengoptimalkan pengetahuan yang dimilikinya melalui sebuah proses. Proses inilah yang membantu siswa untuk mendapatkan solusi yang tepat. 
Novferma (2016: 77) mengatakan bahwa matematika menekankan pada pemecahan masalah, dimana suatu pertanyaan akan menjadi masalah jika seseorang tersebut tidak mempunyai aturan tertentu yang segera dipergunakan untuk menemukan jawaban. Suatu masalah biasanya memuat situasi yang mendorong seseorang untuk memecahkannnya tetapi tidak tahu apa yang harus dikerjakan. Oleh karena itu, jika suatu masalah diberikan kepada seorang siswa, dan siswa tersebut mengetahui langsung jawaban dengan benar terhadap persoalan yang diberikan, maka persoalan tersebut bukan dikatakan sebagai masalah.

Menurut Shadiq (dalam Supriadi, 2015) masalah matematika dapat berupa soal non rutin yang diberikan kepada siswa untuk dikerjakan. Soal non rutin adalah soal yang penyelesaiannya diperlukan pemikiran lebih lanjut karena memerlukan situasi baru yang belum pernah dijumpai siswa sebelumnya. Soal non rutin dapat dipelajari pada materi yang berkaitan dengan persamaan eksponensial, dimana materi tersebut diajarkan pada siswa SMA kelas X semester ganjil. Hal tersebut mengharuskan seorang guru untuk dapat mengoptimalkan siswa dalam menguasai konsep dan memecahkan masalah matematika.

Terdapat kaitan antara pemecahan masalah dan keyakinan diri (self efficacy) siswa, keyakinan diri (self efficacy) memiliki fungsi sebagai alat untuk menilai keberhasilan siswa dalam menyelesaikan soal-soal pemecahan masalah (Jatisunda, 2017: 26). Siswa yang memiliki keyakinan diri (self efficacy) memandang bahwa matematika itu penting untuk kehidupan mereka dan membantu mereka dalam memecahkan masalah matematika dengan menyenangkan, tetapi mereka tidak memiliki keyakinan diri (self efficacy) dapat memecahkan masalah matematika tersebut. Menurut Bandura (dalam Indriani, 2016: 397) keyakinan diri (self efficacy) adalah keyakinan seseorang terhadap keterampilan dan kemampuan dirinya dalam mengorganisasi dan memecahkan permasalahan untuk hasil yang terbaik dalam suatu tugas tertentu. Subaidi (2016: 64) menyatakan bahwa siswa yang memiliki keyakinan diri (self efficacy) akan lebih mampu bertahan menghadapi masalah matematika, mudah memecahkan masalah matematika, dan kegagalan memecahkan masalah matematika tersebut dianggap karena kurangnya usaha atau belajar. Sebaliknya siswa yang tidak memiliki keyakinan diri (self efficacy) cenderung mudah menyerah menghadapi masalah matematika, mengalami kesulitan dalam memecahkan masalah matematika, dan kegagalan memecahkan masalah matematika tersebut dianggap karena kurangnya kemampuan matematikanya. Oleh karena itu, keyakinan diri (self efficacy) setiap siswa dalam memecahkan masalah matematika berbeda-beda. 
Bandura (dalam Sudarno, 2016: 22) mengatakan bahwa terdapat beberapa faktor yang mampu mempengaruhi keyakinan diri (self efficacy) siswa dalam memecahkan masalah matematika, salah satunya yaitu dipengaruhi oleh perbedaan gender. Hal itu sejalan dengan pernyataan Ifdil et al (2016: 31) bahwa terdapat perbedaan antara keyakinan diri (self efficacy) baik siswa perempuan maupun laki-laki. Menurut Santrock (2012: 18) secara teoritis, siswa perempuan berperforma lebih baik daripada laki-laki karena mereka lebih termotivasi dan bekerja lebih tekun dalam melakukan pekerjaan sekolah, keyakinan diri (self efficacy) perempuan lebih baik daripada laki-laki, dan perempuan lebih suka membaca dibandingkan laki-laki. Selain itu, dalam matematika, keyakinan diri (self efficacy) siswa laki-laki adalah lebih tinggi dari siswa perempuan. Dari paparan diatas terlihat bahwa ada perbedaan keyakinan diri (self efficacy) siswa dalam memecahkan masalah matematika yang dipengaruhi oleh perbedaan gender.

Berdasarkan uraian-uraian tersebut, peneliti akan mengadakan penelitian yang berjudul "Analisis Keyakinan Diri (Self Efficacy) Siswa SMA dalam Memecahkan Masalah Matematika Ditinjau dari Perbedaan Gender".

Penelitian ini bertujuan untuk mendeskripsikan keyakinan diri (self efficacy) siswa SMA laki-laki dalam memecahkan masalah matematika dan mendeskripsikan keyakinan diri (self efficacy) siswa SMA perempuan dalam memecahkan masalah matematika.

\section{Metode Penelitian}

Penelitian ini adalah penelitian deskriptif kualitatif. Menurut Moleong (2014: 11) penelitian deskriptif adalah penelitian yang menghasilkan data deskriptif berupa kata-kata tertulis atau lisan dari orang-orang atau perilaku yang dapat diamati. Penelitian deskriptif kualitatif dilakukan untuk memperoleh pengertian yang mendalam mengenai situasi dan makna sesuatu/ subjek yang diteliti (Ulya, 2016) seperti yang dikemukakan oleh Moleong (2014: 6) penelitian kualitatif adalah penelitian yang bermaksud untuk memahami fenomena tentang apa yang dialami subjek penelitian misalnya perilaku, persepsi, motivasi, tindakan, dan lain-lain secara holistik dan dengan cara deskripsi dalam bentuk kata-kata dan bahasa pada suatu konteks khusus yang alamiah dengan memanfaatkan metode alamiah. Hal yang dikaji dalam penelitian ini yaitu keyakinan diri (self efficacy) siswa dalam memecahkan masalah matematika ditinjau dari perbedaan gender. Data yang dihasilkan nantinya berupa kata-kata atau ucapan-ucapan yang diperoleh dari hasil 
wawancara dan tulisan atau bilangan yang diperoleh dari hasil wawancara. Berdasarkan pendekatan kualitatif dalam penelitian ini, semua fakta baik tulisan maupun lisan dari sumber data manusia yang telah diamati dan dokumen terkait lainnya yang diuraikan apa adanya kemudian dikaji seringkas mungkin untuk menjawab permasalahan.

Subjek dalam penelitian ini adalah peserta didik kelas X MIPA 2 di SMA Negeri 1 Kutorejo. Penelitian ini mengambil 2 subjek penelitian yang terdiri dari 1 siswa laki-laki (SL) dan 1 siswa perempuan (SP) yang dilihat berdasarkan data daftar hadir peserta didik kelas X MIPA 2 SMA Negeri 1 Kutorejo. Subjek penelitian yang dipilih adalah siswa yang memiliki kemampuan matematika yang setara dan komunikatif yang didapatkan berdasarkan wawancara guru matematika kelas X. Instrumen penelitian berupa Soal Tes Keyakinan Diri (TKD) dan pedoman wawancara. Kedua subjek penelitian diberi tes keyakinan diri (self efficacy) dan dilakukan wawancara. Kemudian peneliti menganalisis hasil tes dan wawancara sesuai dengan indikator keyakinan diri (self efficacy) siswa dalam memecahkan masalah matematika yaitu memiliki pandangan yang optimis dalam memecahkan masalah matematika, gigih dalam memecahkan masalah matematika, yakin akan kemampuan diri yang dimiliki dalam memecahkan masalah matematika, dan menyikapi situasi dan kondisi yang beragam dengan cara yang baik dan positif dalam memecahkan masalah matematika. Sebelum hasil data dideskripsikan, peneliti menggunakan triangulasi waktu yang digunakan untuk membandingkan dan mengecek balik derajat kepercayaan informasi yang diperoleh melalui waktu yang berbeda. Selanjutnya data yang valid dianalisis dan disimpulkan, dari kesimpulan tersebut diperoleh data keyakinan diri (self efficacy) siswa dalam memecahkan matematika.

\section{Hasil dan Pembahasan}

Berdasarkan hasil analisis data, diperoleh deskripsi keyakinan diri (self efficacy) siswa dalam memecahkan masalah matematika adalah sebagai berikut:

Tabel 1. Deskripsi Keyakinan Diri (Self Efficacy) Siswa dalam Memecahkan Masalah Matematika

\begin{tabular}{|c|c|c|c|}
\hline No & Indikator & Subjek Laki-laki (SP) & Subjek Perempuan (SP) \\
\hline 1 & $\begin{array}{l}\text { Memiliki } \\
\text { pandangan } \\
\text { yang optimis } \\
\text { dalam } \\
\text { memecahkan } \\
\text { masalah } \\
\text { matematika }\end{array}$ & 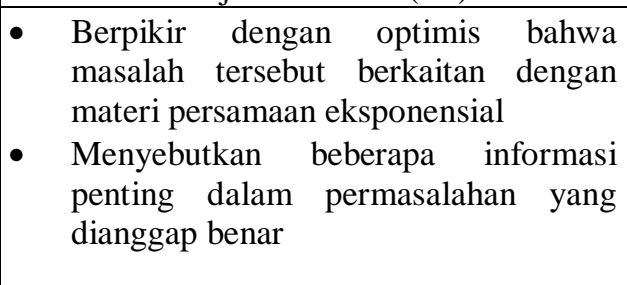 & 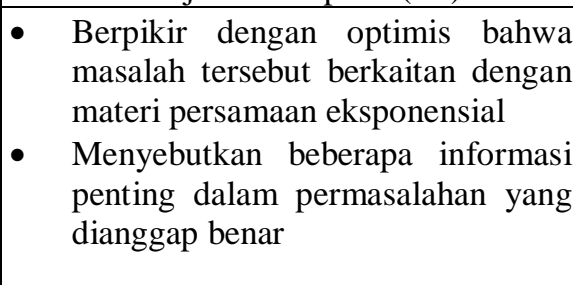 \\
\hline
\end{tabular}




\begin{tabular}{|c|c|c|c|}
\hline No & Indikator & Subjek Laki-laki (SP) & Subjek Perempuan (SP) \\
\hline 1 & $\begin{array}{l}\text { Memiliki } \\
\text { pandangan } \\
\text { yang optimis } \\
\text { dalam } \\
\text { memecahkan } \\
\text { masalah } \\
\text { matematika }\end{array}$ & $\begin{array}{l}\text { - Menyatakan alasannya menuliskan } \\
\text { rumus dan pemisalan tersebut agar } \\
\text { lebih mudah dalam menyelesaikan } \\
\text { permasalahan } \\
\text { - Menyatakan tujuan dari permasalahan } \\
\text { yang diselesaikan, } \\
\text { - Memahami permasalahan tersebut } \\
\text { dengan membaca secara berulang- } \\
\text { ulang } \\
\text { Yakin bahwa strategi yang dilakukan } \\
\text { sudah benar } \\
\text { Menyatakan bahwa strateginya dalam } \\
\text { memecahkan masalah yaitu membaca } \\
\text { permasalahan, menyusun cara } \\
\text { mengerjakan, dikerjakan dan meneliti } \\
\text { kembali hasil pengerjaan } \\
\text { Merasa yakin bahwa apa yang } \\
\text { dipahami itu benar dan penyelesaian } \\
\text { yang ditulis sudah cukup untuk } \\
\text { menentukan jawaban } \\
\text { permasalahan dari }\end{array}$ & 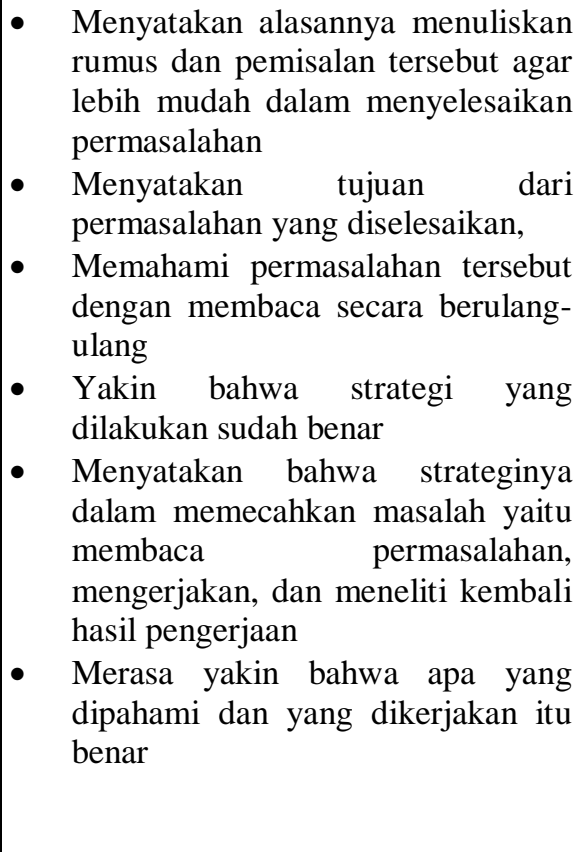 \\
\hline 2 & $\begin{array}{l}\text { Gigih dalam } \\
\text { Memecahkan } \\
\text { Masalah } \\
\text { Matematika }\end{array}$ & $\begin{array}{l}\text { - Tidak merasa putus asa melainkan } \\
\text { lebih tertantang untuk bisa } \\
\text { menyelesaikan permasalahan } \\
\text { - Tidak merasa kesulitan menyelesaikan } \\
\text { permasalahan }\end{array}$ & $\begin{array}{l}\text { - } \text { Tidak merasa putus asa melainkan } \\
\text { lebih tertantang untuk bisa } \\
\text { menyelesaikan permasalahan } \\
\text { - Sedikit merasa kesulitan } \\
\text { menyelesaikan permasalahan }\end{array}$ \\
\hline 3 & $\begin{array}{l}\text { Yakin akan } \\
\text { Kemampuan } \\
\text { Diri yang } \\
\text { Dimiliki } \\
\text { dalam } \\
\text { Memecahkan } \\
\text { Masalah } \\
\text { Matematika }\end{array}$ & 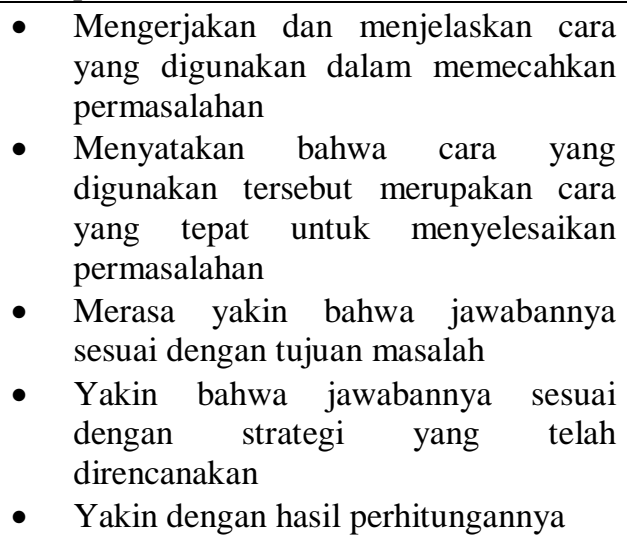 & 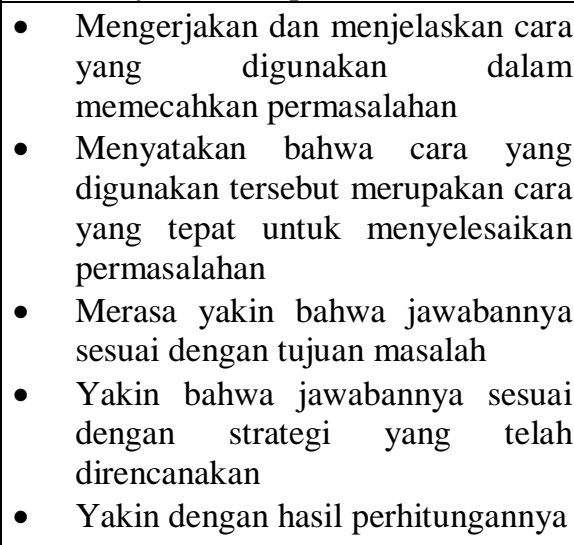 \\
\hline 4 & $\begin{array}{l}\text { Menyikapi } \\
\text { situasi dan } \\
\text { kondisi yang } \\
\text { beragam } \\
\text { dengan cara } \\
\text { yang baik dan } \\
\text { positif dalam } \\
\text { memecahkan } \\
\text { masalah } \\
\text { matematika }\end{array}$ & 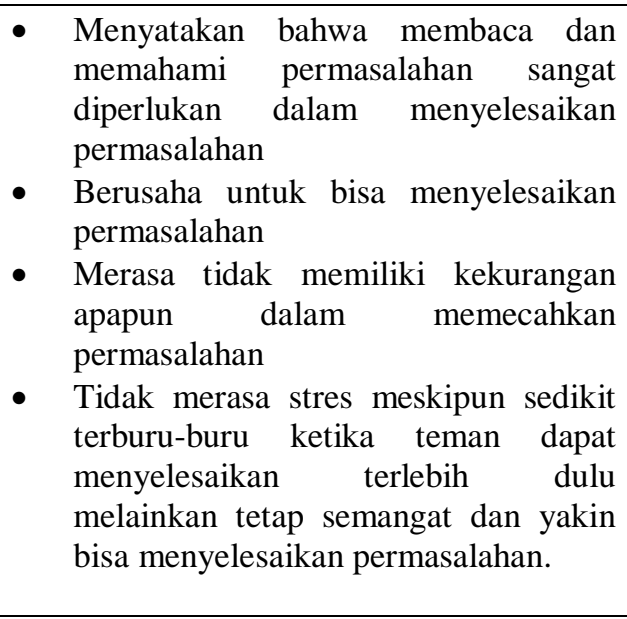 & 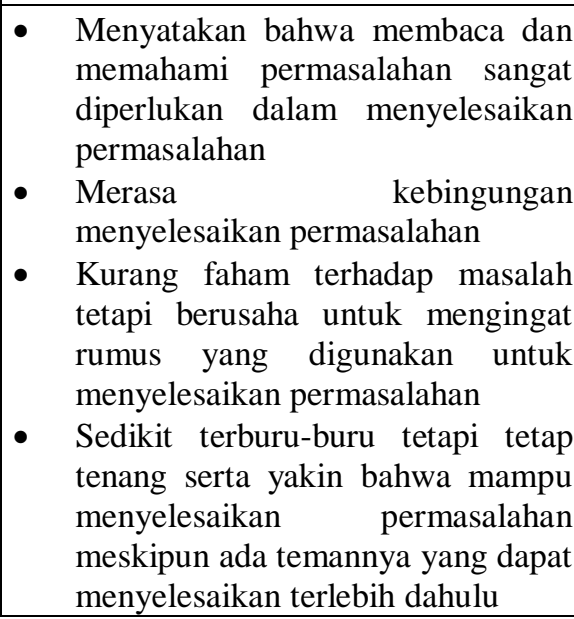 \\
\hline
\end{tabular}


Berdasarkan Tabel 1. Deskripsi Keyakinan Diri (Self Efficacy) Siswa dalam Memecahkan Masalah Matematika, dapat dibahas sebagai berikut.

1. Keyakinan Diri (Self Efficacy) Siswa SMA Laki-laki dalam Memecahkan Masalah Matematika

Keyakinan diri (self efficacy) siswa SMA laki-laki dalam memecahkan matematika pada indikator memiliki pandangan yang optimis dalam memecahkan masalah matematika, subjek berpikir dengan optimis bahwa masalah tersebut berkaitan dengan materi persamaan eksponensial dan menyebutkan beberapa informasi penting dalam permasalahan yang dianggap benar, menyatakan alasannya menuliskan pemisalan tersebut agar lebih mudah dalam menyelesaikannya, menyatakan tujuan dari permasalahan yang diselesaikan, dan memahami permasalahan tersebut dengan membaca secara berulangulang. Hal tersebut sesuai dengan pernyataan Sudia (2015) bahwa siswa laki-laki menyadari pentingnya cara memahami masalah yaitu dilakukan dengan cara membaca masalah beberapa kali.

Selain itu, subjek merasa yakin bahwa apa yang dipahami itu benar dan penyelesaian yang ditulis sudah cukup untuk menentukan jawaban dari permasalahan, menyatakan bahwa strateginya dalam memecahkan masalah yaitu membaca permasalahan, menyusun cara mengerjakan, dikerjakan, dan meneliti kembali pengerjaannya, serta yakin bahwa strategi yang dilakukan sudah benar. Hal tersebut sesuai dengan pernyataan Sudia (2015) bahwa siswa laki-laki menyadari pentingnya memeriksa pemahaman terhadap masalah dan memeriksa kesesuaian yang diungkapkan dari apa yang dipahami pada masalah dan dilakukan dengan cara memperhatikan kembali masalah.

Pada indikator gigih dalam memecahkan masalah matematika, subjek tidak merasa kesulitan menyelesaikan permasalahan dan tidak merasa putus asa melainkan lebih tertantang untuk bisa menyelesaikan permasalahan. Hal tersebut sesuai dengan pendapat Sudia (2015) bahwa siswa laki-laki memiliki kemampuan metakognisi yang baik.

Pada indikator yakin akan kemampuan diri yang dimiliki dalam memecahkan masalah matematika, subjek mengerjakan dan menjelaskan cara yang digunakan dalam memecahkan permasalahan, menyatakan bahwa cara yang digunakan tersebut merupakan cara yang tepat untuk menyelesaikan permasalahan, merasa yakin bahwa jawabannya sesuai dengan tujuan masalah, yakin bahwa jawabannya sesuai dengan strategi yang telah direncanakan, dan yakin dengan hasil perhitungannya. Beberapa hal diatas sesuai dengan 
pendapat Santrock (2012) bahwa siswa laki-laki memiliki keyakinan diri yang tinggi dalam matematika.

Pada indikator menyikapi situasi dan kondisi yang beragam dengan cara yang baik dan positif dalam memecahkan masalah matematika, subjek berusaha untuk bisa menyelesaikan permasalahan, menyatakan bahwa membaca, dan mengingat rumus sangat diperlukan dalam menyelesaikan permasalahan, merasa tidak memiliki kekurangan apapun dalam memecahkan permasalahan,dan tidak merasa stres meskipun sedikit terburu-buru ketika teman dapat menyelesaikan permasalahan terlebih dahulu melainkan tetap semangat dan yakin bisa menyelesaikan permasalahan tepat waktu.

2. Keyakinan Diri (Self Efficacy) Siswa SMA Perempuan dalam Memecahkan Masalah Matematika

Keyakinan diri (self efficacy) siswa SMA perempuan dalam memecahkan matematika pada indikator memiliki pandangan yang optimis dalam memecahkan masalah matematika, subjek berpikir dengan optimis bahwa masalah tersebut berkaitan dengan materi persamaan eksponensial dan menyebutkan beberapa informasi penting dalam permasalahan yang dianggap benar, menyatakan alasannya menuliskan rumus dan pemisalan tersebut agar lebih mudah dalam menyelesaikannya, menyatakan tujuan dari permasalahan yang diselesaikan, dan memahami permasalahan tersebut dengan membaca secara berulang-ulang. Berdasarkan hal tersebut sesuai dengan pendapat Sudia (2015) bahwa siswa perempuan menyadari pentingnya cara memahami masalah yaitu dilakukan dengan cara membaca masalah beberapa kali sampai masalah benar-benar dipahami.

Selain itu subjek merasa yakin bahwa apa yang dipahami dan yang dikerjakan itu benar, menyatakan bahwa strateginya dalam memecahkan masalah yaitu membaca permasalahan, mengerjakan, dan meneliti kembali pengerjaannya, serta yakin bahwa strategi yang dilakukan sudah benar. Hal tersebut sesuai dengan pernyataan Sudia (2015) bahwa siswa perempuan menyadari pentingnya mengecek pemahaman terhadap masalah.

Pada indikator gigih dalam memecahkan masalah matematika, subjek sedikit merasa kesulitan menyelesaikan permasalahan dan tidak merasa putus asa melainkan lebih tertantang untuk bisa menyelesaikan permasalahan. Beberapa hal tersebut sesuai dengan pendapat Santrock (2012) bahwa siswa perempuan lebih termotivasi dan bekerja lebih tekun dalam melakukan pekerjaan sekolah.

Pada indikator yakin akan kemampuan diri yang dimiliki dalam memecahkan masalah matematika, subjek menjelaskan cara yang digunakan dalam memecahkan 
permasalahan, menyatakan bahwa cara yang digunakan tersebut merupakan cara yang tepat untuk menyelesaikan permasalahan, merasa yakin bahwa jawabannya sesuai dengan tujuan masalah, yakin bahwa jawabannya sesuai dengan strategi yang telah direncanakan, dan yakin dengan hasil perhitungannya. Beberapa hal tersebut di atas sesuai dengan pendapat Santrock (2012) bahwa siswa perempuan memiliki keyakinan diri yang lebih baik daripada laki-laki.

Pada indikator menyikapi situasi dan kondisi yang beragam dengan cara yang baik dan positif dalam memecahkan masalah matematika, subjek merasa kebingungan menyelesaikan permasalahan, menyatakan bahwa membaca dan memahami permasalahan sangat diperlukan dalam menyelesaikan permasalahan, kurang faham terhadap masalah tetapi berusaha untuk mengingat rumus yang digunakan untuk menyelesaikan permasalahan, dan sedikit terburu-buru tetapi tetap tenang serta yakin bahwa mampu menyelesaikan permasalahan meskipun ada temannya yang dapat menyelesaikan terlebih dahulu. Hal tersebut sesuai dengan pendapat Santrock (2012) bahwa siswa perempuan memiliki keyakinan diri yang lebih baik daripada laki-laki.

Pada penelitian ini, peneliti menyimpulkan bahwa keyakinan diri (self efficacy) siswa SMA laki-laki dan siswa SMA perempuan dalam memecahkan masalah matematika memiliki perbedaan. Hal tersebut sejalan dengan penelitian Ifdil et al (2016), yang menyimpulkan bahwa terdapat perbedaan antara keyakinan diri (self efficacy) baik siswa perempuan maupun laki-laki.

\section{Simpulan dan Saran}

Berdasarkan hasil penelitian dan pembahasan yang dilakukan terhadap subjek penelitian maka dapat ditarik kesimpulan sebagai berikut:

1. Keyakinan diri (self efficacy) siswa SMA laki-laki dalam memecahkan masalah matematika

Pada indikator memiliki pandangan yang optimis dalam memecahkan masalah matematika, subjek berpikir dengan optimis bahwa masalah tersebut berkaitan dengan materi persamaan eksponensial dan menyebutkan beberapa informasi penting dalam permasalahan yang dianggap benar, menyatakan alasannya menuliskan pemisalan tersebut agar lebih mudah dalam menyelesaikannya, menyatakan tujuan dari permasalahan yang diselesaikan, dan memahami permasalahan tersebut dengan membaca secara berulang- 
ulang. Selain itu, subjek merasa yakin bahwa apa yang dipahami itu benar dan penyelesaian yang ditulis sudah cukup untuk menentukan jawaban dari permasalahan, menyatakan bahwa strateginya dalam memecahkan masalah yaitu membaca permasalahan, menyusun cara mengerjakan, dikerjakan, dan meneliti kembali pengerjaannya, serta yakin bahwa strategi yang dilakukan sudah benar.

Pada indikator gigih dalam memecahkan masalah matematika, subjek tidak merasa kesulitan menyelesaikan permasalahan dan tidak merasa putus asa melainkan lebih tertantang untuk bisa menyelesaikan permasalahan.

Pada indikator yakin akan kemampuan diri yang dimiliki dalam memecahkan masalah matematika, subjek menjelaskan cara yang digunakan dalam memecahkan permasalahan, menyatakan bahwa cara yang digunakan tersebut merupakan cara yang tepat untuk menyelesaikan permasalahan, merasa yakin bahwa jawabannya sesuai dengan tujuan masalah, yakin bahwa jawabannya sesuai dengan strategi yang telah direncanakan, dan yakin dengan hasil perhitungannya.

Pada indikator menyikapi situasi dan kondisi yang beragam dengan cara yang baik dan positif dalam memecahkan masalah matematika, subjek berusaha untuk bisa menyelesaikan permasalahan, menyatakan bahwa membaca, dan mengingat rumus sangat diperlukan dalam menyelesaikan permasalahan, merasa tidak memiliki kekurangan apapun dalam memecahkan permasalahan,dan tidak merasa stres meskipun sedikit terburu-buru ketika teman dapat menyelesaikan permasalahan terlebih dahulu melainkan tetap semangat dan yakin bisa menyelesaikan permasalahan.

2. Keyakinan diri (self efficacy) siswa SMA perempuan dalam memecahkan masalah matematika

Pada indikator memiliki pandangan yang optimis dalam memecahkan masalah matematika, subjek berpikir dengan optimis bahwa masalah tersebut berkaitan dengan materi persamaan eksponensial dan menyebutkan beberapa informasi penting dalam permasalahan yang dianggap benar, menyatakan alasannya menuliskan rumus dan pemisalan tersebut agar lebih mudah dalam menyelesaikannya, menyatakan tujuan dari permasalahan yang diselesaikan, dan memahami permasalahan tersebut dengan membaca secara berulang-ulang. Selain itu subjek merasa yakin bahwa apa yang dipahami dan yang dikerjakan itu benar, menyatakan bahwa strateginya dalam memecahkan masalah yaitu membaca permasalahan, mengerjakan, dan meneliti kembali pengerjaannya, serta yakin bahwa strategi yang dilakukan sudah benar. 
Pada indikator gigih dalam memecahkan masalah matematika, subjek sedikit merasa kesulitan menyelesaikan permasalahan dan tidak merasa putus asa melainkan lebih tertantang untuk bisa menyelesaikan permasalahan.

Pada indikator yakin akan kemampuan diri yang dimiliki dalam memecahkan masalah matematika, subjek menjelaskan cara yang digunakan dalam memecahkan permasalahan, menyatakan bahwa cara yang digunakan tersebut merupakan cara yang tepat untuk menyelesaikan permasalahan, merasa yakin bahwa jawabannya sesuai dengan tujuan masalah, yakin bahwa jawabannya sesuai dengan strategi yang telah direncanakan, dan yakin dengan hasil perhitungannya.

Pada indikator menyikapi situasi dan kondisi yang beragam dengan cara yang baik dan positif dalam memecahkan masalah matematika, subjek merasa kebingungan menyelesaikan permasalahan, menyatakan bahwa membaca dan memahami permasalahan sangat diperlukan dalam menyelesaikan permasalahan, kurang faham terhadap masalah tetapi berusaha untuk mengingat rumus yang digunakan untuk menyelesaikan permasalahan, dan sedikit terburu-buru tetapi tetap tenang serta yakin bahwa mampu menyelesaikan permasalahan meskipun ada temannya yang dapat menyelesaikan terlebih dahulu.

Adapun saran dalam penelitian ini sebagai berikut.

1. Bagi guru sebaiknya guru mempertimbangkan perbedaan gender terhadap keyakinan diri (self efficacy) siswa dalam memecahkan masalah matematika

2. Kajian dalam penelitian ini masih terbatas, sehingga bagi peneliti lain yang hendak melakukan penelitian terkait keyakinan diri (self efficacy) dalam memecahkan masalah matematika sebaiknya meninjau ulang pedoman wawancara guna mengumpulkan informasi lebih dalam terkait keyakinan diri (self efficacy) dalam memecahkan masalah matematika.

3. Agar mendapat hasil penelitian yang lebih baik pada penelitian yang sejenis, maka sebaiknya kelemahan-kelemahan pada penelitian ini harap diperhatikan dan diminimalisir pada penelitian selanjutnya, sehingga kesalahan-kesalahan yang terjadi pada penelitian ini tidak terulang kembali 


\section{Referensi}

Arikunto, S. 2010. Manajemen Penelitian. Jakarta: Rineka Cipta.

Arikunto, S. 2012. Dasar-dasar Evaluasi Pendidikan. Jakarta: Bumi Aksara.

Cahyono, S. D. 2016. Pengaruh Self Efficacy dan Motivasi Belajar terhadap Hasil Belajar Matematika Siswa Kelas VIII SMP Negeri 22 Surabaya pada Materi Lingkaran. Skripsi tidak diterbitkan. Surabaya: Universitas Negeri Surabaya.

Depdiknas. 2008. Kamus Besar Bahasa Indonesia (KBBI) Pusat Bahasa. Jakarta: Gramedia Pustaka Utama.

Elisa, S. N. 2016. Analisis Kesalahan Siswa Kelas VII dalam Menyelesaikan Soal Pemecahan Masalah ditinjau dengan Prosedur Newman. Skripsi Online. Semarang: Universitas Negeri Semarang.

Gista Ayu Kusuma Wardani, T. N. 2017, Desember. Analisis Metakognisi Siswa dalam Memecahkan Masaah Matematika Materi SPLDV ditinjau dari Perbedaan Gender. Jurnal Mitra Pendidikan Online, 1, 1031-1045.

Hidayat, T. 2017. Strategi Mahasiswa dalam Memecahkan Permasalahan Non Rutin pada Materi Aljabar. Skripsi Online. Surakarta: Universitas Muhammadiyah Surakarta.

Hidayati, D. N. 2015. Analisis Kesalahan Siswa SMP Dalam Memecahkan Masalah Matematika Berdasarkan Tahapan Newman pada Materi Sistem Persamaan Linear Dua Variabel. Skripsi tidak diterbitkan. Surabaya: Universitas Negeri Surabaya.

Ifdil, Rizka Apriani, Frischa Meivilona Yendi, Itsar Bolo Rangka. 2016, December 31. Level of Students'Self-Efficacy Based on Gender. The International Journal of Counseling and Education, 1, 30.

Indriani, N. 2016. Proses Berpikir Siswa dalam Pemecahan Masalah Trigonometrii ditinjau dari Self Efficacy Siswa. Skripsi tidak diterbitkan. Surabaya: Universitas Negeri Surabaya.

Iswahyudi, G. 2012. Aktivitas Metakognisi dalam Memecahkan Masalah Pembuktian Langsung ditinjau dari Gender dan Kemampuan Matematika. Prosiding SNMPM 2012 (pp. 88-102). Surakarta: Universitas Sebelas Maret.

Jatisunda, M. G. 2017. Hubungan Self Efficacy Siswa SMP dengan Kemampuan Pemecahan Masalah Matematis. Jurnal THEOREMS (The Original Research of Mathematics, 1, 24-30.

Khair, A. M. 2017. Analisis Proses Berpikir dalam Pemecahan Masalah dengan Kategori Menurut Polattsek ditinjau dari Self efficacy pada Siswa Kelas VII di SMP 21 Bandarlampung Tahun Ajaran 2016/2017. Skripsi Online. Bandar Lampung.

Kusumawati dan Nayazik. 2017, Juli. Kecemasan Matematika Siswa SMA Berdasarkan Gender. Journal of Medives, 1, 93.

Lestari S, Waluya B, dan Suyitno H. 2015. Analisis Kemampuan Keruangan dan Self Efficacy Peserta Didik dalam Model Pembelajaran Trefingger Berbasis budaya Demak. Unnes Journal of Mathematics Education Research. 
Malik, N. Q. 2011. Analisis Kesalahan Siswa Kelas VII SMP Negeri 4 Kudus Dalam Menyelesaikan Soal Matematika.

Moleong, L. J. 2014. Metodologi Penelitian Kualitatif. Bandung: Remaja Rosdakarya.

Nafiah, M. N. 2017. Identifikasi Tahap Pemahaman Geometri Siswa Berdasarkan Teori Van Hiele Ditinjau dari Perbedaan Gender pada Materi Persegi Panjang Kelas VII SMP. Skripsi Online. Surabaya: FMIPA universitas Negeri Surabaya.

Novferma, N. 2016, Mei. Analisis Kesulitan dan Sellf efficacy Siswa SMP dalam Pemecahan Masalah Matematika Berbentuk Soal Cerita. Jurnal Riset Pendidikan Matematika, 3, 76.

Novi Indriani, Endah Budi Rahaju. 2016. Proses Berpikir Siswa dalm Pemecahan Masalah Trigonometri Ditinjau dari Self Efficacy. Jurnal Ilmiah Pendidikan Matematika, 3, 395.

Pratiwi, D. D. 2015. Analisis Kemampuan Komunikasi Matematis dalam Pemecahan Masalah Matematika Sesuai dengan Gaya Kognitif dan Gender. Jurnal Pendidikan Matematika, 131-141.

Rahmayanti, T. Y. 2016. Analisis Proses Berpikir Dalam Memecahkan Masalah Matematika Polya Siswa Kelas XI SMAN 1 Bangsri Jepara Berdasarkan Tipe Kepribadian. Skripsi Online. Semarang: Fakultas Sains dan Teknologi Universitas Islam Negeri Walisongo.

Retno Sari, T. A. 2014. Aktivitas Metakognisi Dalam Pemecahan Masalah Matematika Ditinjau Dari Gender Siswa Kelas VII SMP Negeri 1 Nanggulan Kabupaten Kulon Progo. Jurnal Pendidikan Matematika UNS, 3.

Rofiqoh, Z. 2015. Analisis Kemampuan Pemecahan Masalah Matematika Siswa Kelas X Dalam Pembelajaran Discovery Learning Berdasakan Gaya Belajar Siswa. Skripsi Online. Semarang: UNNES.

Ruhyana. 2016, Desember. Analisis Kesulitan Siswa Dalam Memecahkan Masalah Matematika. Jurnal Computech dan Bisnis, 10, 108.

Safitri, I. N. 2016. Analisis Kemampuan Literasi Matematis Siswa dalm Perspektif Gender. Skripsi Online. Surabaya: UIN Sunan Ampel Surabaya.

Santrock, J. W. 2012. Life Span Development-Perkembangan Masa Hidup.(Online)

Sari, R. T. 2014. Aktivitas Metakognisi Dalam Pemecahan Masalah Matematika Ditinjau Dari Gender Siswa Kelas VII SMP Negeri 1 Nanggulan Kabupaten Kulon Progo. Jurnal Pendidikan Matematika UNS, 3.

Sholikhah, N. Q. 2017. Analisis Tingkat Self Efficacy dalam Menyelesaikan Masalah Mamatia Siswa dibedakan dari Gaya Kognitif Reflektif dan Impulsif. Skripsi Online. Surabaya: Universitas Islam Negeri Sunan Ampel Surabaya.

Smetackova, I. 2015. Gender Stereotypes, Performance and Identification with Math. ProcediaSocial and Behavioral Sciences, 211-219. 
Subaidi, A. 2016. Self Efficacy Siswa Dalam Pemecahan Masalah Matematika. Jurnal Pendidikan Matematika Universitas Madura, 64-68.

Subarinah. 2013. Profil Berpikir Kreatif Siswa dalam Memecahkan Masalah Tipe Investigasi Matematika Ditinjau dari Perbedaan Gender. Jurnal Pendidikan Matematika, 524.

Sudarno, B. E. 2016. Hubungan Self Efficacy Berdasarkan Gender dengan Hasil Belajar Siswa pada Materi Pelajaran IPA Kelas VIII SMP Se-Kecamatan Gadingrejo. Skripsi Online. Bandar Lampung: Fakultas Keguruan dan Ilmu Pendidikan Universitas Bandar Lampung.

Sudia. (2015). Profil Metakognisi Siswa SMP dalam Memecahkan Masalah Matematika Terbuka Ditinjau dari Perbedaan Gender. Jurnal Pendidikan dan Pembelajaran, 22(1)

Sugiyono. 2016. Metode Penelitian Kuantitatif, Kualitatif, dan $R \&$ D. Bandung: Alfabeta.

Supriadi. 2015. Pengaruh Keyakinan Diri, Kesadaran Diri, dan Pengetahuan Kognitif Siswa Terhadap Kemampuan Pemecahan Masalah Matematika. Skripsi tidak diterbitkan. Surabaya: UNESA.

Ulya, H. 2016. Profil Kemampuan Pemecahan Masalah Siswa Bermotivasi Belajar Tinggi Berdasarkan IDEAL Problem Solving. Jurnal Konseling GUSJIGANG, 2.

Uray Windi Haryandika, C. U. 2017, September. Analisis Kelancaran Prosedural pada Materi Persamaan Eksponen Kelas X SMA Negeri 2 Singkawang. Jurnal Pendidikan Matematika Indonesia, 2, 72-77.

Urte Scholz, Benicio Gutierrez Dona, Shonali Sud, Ralf Schwarzer. 2002. Is General Self Efficacy a Universal Construct. Europan Journal of Psychological Assessment, $18(3), 242-251$.

Wijaya, A. A. 2013. Analisis Kesalahan Siswa Dalam Menyelesaikan Soal Cerita Materi $S P L D V$. Skripsi tidak diterbitkan. Surabaya: Universitas Negeri Surabaya. 